\title{
A Rare Mimicker of an Adrenal Carcinoma: Co-occurrence of Hemorrhagic Pseudocyst and Myelolipoma
}

\author{
Adrenal Karsinomun Nadir Bir Taklitçisi: Hemorajik Psödokist ve Miyelolipomun Birlikte \\ Olușumu
}

\author{
(D) Cihan Kalkan11, (D) Serdar Aslan11, (D) Illkay Çamlıdağ11, (D) Mehmet Selim Nural1, (D) Murat Danacı1, (D) Mesut Öztürk1, \\ (D) Mehmet Kefeli2 \\ 1Ondokuz Mayıs University Faculty of Medicine, Department of Radiology, Samsun, Turkiye \\ 2Ondokuz Mayıs University Faculty of Medicine, Department of Pathology, Samsun, Turkiye
}

\begin{abstract}
Adrenal collision tumors are rare tumors composed of two different benign or malignant tumors in the adrenal gland. Radiological features are very helpful in the diagnosis, however it is not always possible to make a definite diagnosis with imaging findings alone because the coexisting masses contain different tissue components. In this paper, we report the imaging findings of an adrenal lesion with pseudocyst and myelolipoma mimicking an adrenocortical carcinoma in a 42-year-old female patient. To the best of our knowledge, this is the first reported case of an adrenal lesion containing myelolipoma and hemorrhagic pseudocyst mimicking an adrenal carcinoma in the literature.
\end{abstract}

Keywords: Adrenal lesions, Adrenal pseudocyst, Myelolipoma, Computed tomography, Magnetic resonance imaging

Öz

Adrenal kollizyon tümörleri, adrenal bezde iki farklı benign veya malign tümörden oluşan nadir tümörlerdir. Radyolojik özellikler tanıda çok yardımcıdır, ancak farklı doku bileşenleri içerdiği için tek başına görüntüleme bulguları ile kesin bir tanı koymak her zaman mümkün değildir. Bu sunumda; 42 yaşında bir kadın hastada adrenokortikal karsinomu taklit eden psödokist ve miyelolipom içeren bir adrenal lezyonun görüntüleme bulgularını sunuyoruz. Bildiğimiz kadarıyla, literatürde ilk kez adrenal karsinomu taklit eden miyelolipom ve hemorajik psödokist içeren adrenal lezyon bildirilmiştir.

Anahtar Kelimeler: Adrenal lezyonlar, Adrenal psödokist, Miyelolipom, Bilgisayarlı tomografi, Manyetik rezonans görüntüleme

\section{Introduction}

Adrenal collision tumor is the simultaneous co-occurrence of two different benign or malignant tumors in the adrenal gland (1). It is often unilateral, asymptomatic and incidentally detected. It can cause symptoms related to compression to surrounding tissues when it enlarges. It may contain two different primary tumors or one primary tumor and a metastasis. Both tumors may be malignant, one may be malignant and the other may be benign, or both may be benign (2). Radiological findings are very helpful in the diagnosis. However, it is not always possible to make a definite diagnosis with imaging findings alone, because the coexisting masses contain different tissue components. In this paper, we report imaging findings of an adrenal tumor containing a pseudocyst and a myelolipoma which was confused with adrenocortical carcinoma.

\section{Case Presentation}

A 42-year-old female patient was admitted to the urology clinic at our hospital with the complaints of pain radiating from the left upper quadrant and epigastric region to the back. Physical examination revealed a palpable mass in the left lumbar

Correspondence: Cihan Kalkan MD, Ondokuz Mayıs University Faculty of Medicine, Department of Radiology, Samsun, Turkiye

Phone: +90362 3121919 E-mail: cihankalkan_dr@hotmail.com ORCID-ID: orcid.org/0000-0002-8906-2608

Received: 09.03.2018 Accepted: 01.05.2018

Cite this article as: Kalkan C, Aslan S, Çamlıdağ I, Nural MS, Danacı M, Öztürk M, Kefeli M. A Rare Mimicker of an Adrenal Carcinoma: Co-occurrence of Hemorrhagic Pseudocyst and Myelolipoma. J Urol Surg 2018;5(4):224-226. 
area. Complete blood count, hepatic and renal function tests, electrolytes, and urinalysis were all within the normal limits. Intravenous contrast-enhanced computed tomography (CT) scan was subsequently performed. CT revealed a well circumscribed, internally heterogeneous, progressively enhancing, 140×123 $\mathrm{mm}$ mass in the left adrenal gland with areas of fat attenuation and calcifications (Figure 1). The adrenal gland was indistinguishable from the tumor. Malignant adrenal masses, primary adrenocortical carcinoma, retroperitoneal teratomas and mesenchymal tumors were considered in the differential diagnosis. Twenty-four-hour urine vanillylmandelic acid, homovanillic acid and 5-hydroxyindoleacetic acid values were within the normal limits, ruling out pheochromocytoma. Blood adrenaline, noradrenaline, metanephrine, normetanephrine and adrenocorticotropic hormone levels were also normal. Magnetic resonance imaging (MRI) was performed to evaluate the internal structure of the tumor better and to make a differential diagnosis.

MRI showed a well circumscribed, heterogeneously enhancing

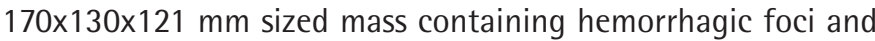
focal fat tissues (Figure 2). All imaging findings were suggestive of adrenal malignant tumors, primarily adrenocortical carcinoma, secondarily teratomas or mesenchymal tumors. With these findings, the patient underwent surgery and left adrenalectomy was performed. Pathologically, the material was reported to be composed entirely of large necrosis and bleeding areas with focal calcifications and multiloculated cysts without epithelium. In addition, a focus compatible with myelolipoma was observed in a limited area, and the diagnosis was interpreted as an adrenal hemorrhagic pseudocyst and concomitant myelolipoma. No malignant component was found.

All of the procedures described in this report were standard of care and the patient provided informed consent for the standard of care procedures according to hospital policy. No informed consent for this report was needed as this was not a research study.

\section{Discussion}

The pathogenesis of adrenal collision tumors is still controversial, because the limited number of cases in the literature prevents detailed analysis of the etiology. Two separate theories have been proposed to explain the pathogenesis $(3,4)$. The first and simplest explanation is the simultaneous formation of two distinct primary tumor centers only by chance. The secondary hypothesis is that a carcinogenic stimulus permits two different tumors to form adjacent to each other by altering a specific region in the adrenal gland, or the first tumor provides a fertile ground allowing the secondary tumor to form, by affecting the local environment.
Adrenal collision tumors are most commonly composed of adenomas and metastatic components (5). This can be explained by the high incidence of adenomas and the high tendency of adrenal glands to metastases (6). More rarely, adenomapheochromocytoma, adenoma-hemangioma, adrenocortical carcinoma-metastasis, adrenocortical carcinoma-myelolipoma, carcinosarcoma-metastasis, and myelolipoma-Hodgkin's lymphoma have been reported in the literature. Collision tumors with cystic lesion component are rare and there is limited number of reported cases (2). According to our knowledge of the current literature, there has been no report of an adrenal lesion

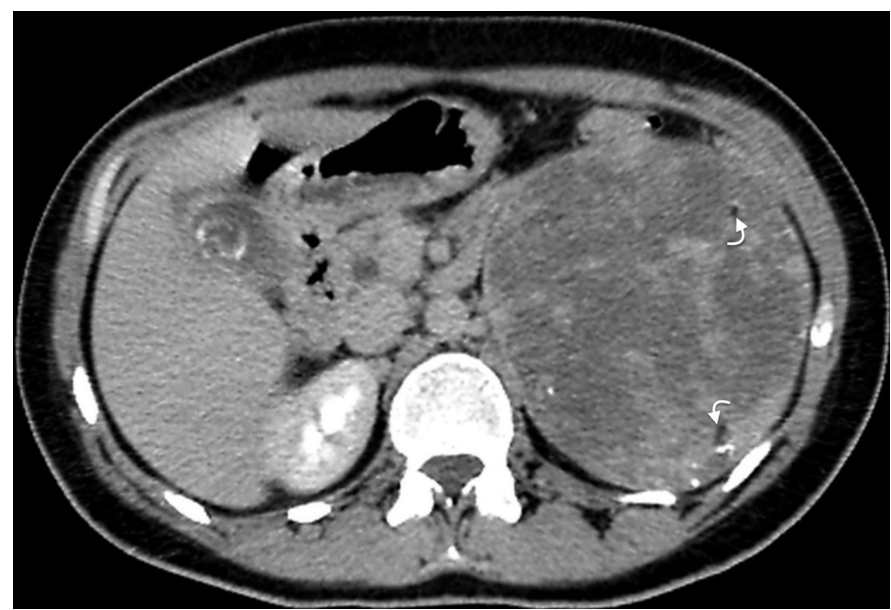

Figure 1. Axial contrast-enhanced computed tomography image of the abdomen shows a large mass in the left upper quadrant which contains calcifications and fat-attenuated areas (curved arrows)

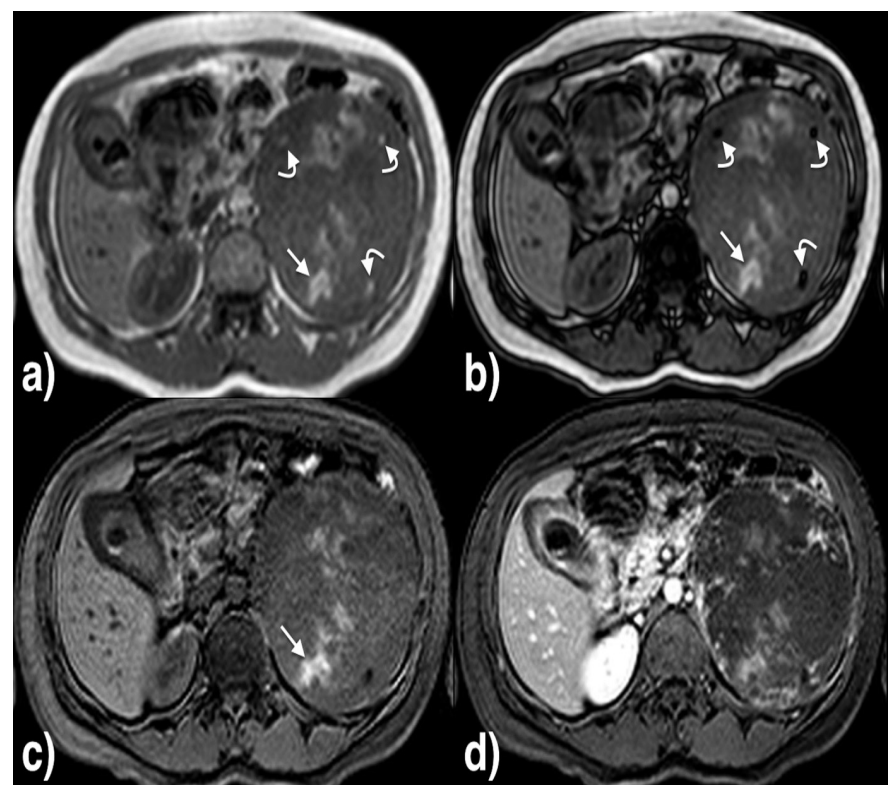

Figure 2. a) Axial T1-weighted in-phase, b) T1-weighted out-phase, c) noncontrast enhanced fat suppressed T1-weighted and d) contrast enhanced fat suppressed T1-weighted images of the mass are shown. The mass contains fat tissue which is demonstrated as signal dropped areas on T1-weighted outphase and fat suppressed T1-weighted images (curved arrows). There is also significant amount of hemorrhage (arrows) 
consisting of the combination of pseudocyst and myelolipoma as in our case. Like collision tumors, both neoplastic and nonneoplastic lesions can be seen together in adrenal lesions. This cooccurrence makes a definite diagnosis challenging as in our case.

Adrenal pseudocysts are rare, asymptomatic and mostly benign cysts. They are often seen after trauma or with a history of previous pancreatitis. Symptomatic cases may present with gastrointestinal symptoms, flank pain, and palpable mass depending on the lesion size $(7,8)$. In the literature, the estimated risk of a pseudocyst being malignant has been reported to be $7 \%$. The risk of malignancy increases with size especially for masses larger than $6 \mathrm{~cm}(9,10,11)$. Especially when hemorrhage occurs within the pseudocyst, the cyst enlarges and it can be confused with malignant lesions. In our case, due to bleeding into the pseudocyst, MRI findings were suggestive of an adrenocortical carcinoma. However, the presence of fat is not a common finding in adrenocortical carcinomas (12). Therefore, retroperitoneal teratomas or fat-containing mesenchymal tumors were considered in the differential diagnosis.

Pheochromocytoma should also be considered in differential diagnosis of adrenal masses. Radiologically, pheochromocytomas are unilateral, solitary, oval or round, well-circumscribed, heterogeneous cystic masses usually larger than $3 \mathrm{~cm}$ in diameter. On CT, they demonstrate vivid arterial enhancement and wash-out on delayed phase. On MRI, they are usually hypointense on T1-weighted images, markedly hyperintense on T2-weighted images and enhance heterogeneously after the administration of intravenous contrast agent. There is no signal loss on T1-out phase images since they do not usually contain intracellular fat (13). However, regardless of the lesion size, degeneration, necrosis, cystic changes and rarely microscopic or macroscopic fat can be seen $(14,15,16)$. In these situations, it may be confused with adrenocortical carcinoma and metastasis. Pheochromocytoma was not considered in our case as clinical and laboratory findings ruled out pheochromocytoma and there was no wash-out on dynamic imaging.

In conclusion, pseudocyst with accompanying myelolipoma is very rare among adrenal tumors. The radiological findings of different histological components of hemorrhagic pseudocyst and myelolipoma make it difficult to distinguish from adrenocortical carcinomas and other retroperitoneal tumors occupying adrenal region.

\section{Ethics}

Informed Consent: All of the procedures described in this report were standard of care and the patient provided informed consent for the standard of care procedures according to hospital policy. No informed consent for this report was needed as this was not a research study.

Peer-review: Externally peer-reviewed.

\section{Authorship Contributions}

Surgical and Medical Practices: C.K., S.A., I.Ç., M.S.N., M.D., M.Ö., M.K., Concept: C.K., S.A., I.Ç., M.S.N., M.D., M.Ö., M.K., Design: C.K., S.A., I.Ç., M.S.N., M.D., M.Ö., M.K., Data Collection or Processing: C.K., S.A., I.Ç., M.S.N., M.D., M.Ö., M.K., Analysis or Interpretation: C.K., S.A., i.Ç., M.S.N., M.D., M.Ö., M.K., Literature Search: C.K., S.A., I.Ç., M.S.N., M.D., M.Ö., M.K., Writing: C.K., S.A., i.Ç., M.S.N., M.D., M.Ö., M.K.

Conflict of Interest: No conflict of interest was declared by the authors.

Financial Disclosure: The authors declared that this study received no financial support.

\section{References}

1. Siddiqi AJ, Miller FH, Kasuganti D, Nikolaidis P. Adrenal hemangiomaadenoma: an exceedingly rare adrenal collision tumor. J Magn Reson Imaging 2009;29:949-952.

2. Katabathina VS, Flaherty E, Kaza R, Ojili V, Chintapalli KN, Prasad SR Adrenal collision tumors and their mimics: multimodality imaging findings. Cancer Imaging 2013;13:602-610.

3. Schwartz LH, Macari M, Huvos AG, Panicek DM. Collision tumors of the adrenal gland: demonstration and characterization at $\mathrm{MR}$ imaging. Radiology 1996;201:757-760.

4. Anderson SB, Webb MD, Banks KP. Adrenal collision tumor diagnosed by F-18 fluorodeoxyglucose PET/CT. Clin Nucl Med 2010;35:414-417.

5. Hagspiel KD. Manifestation of Hodgkin's lymphoma in an adrenal myelolipoma. Eur Radiol 2005;15:1757-1759.

6. Taffel M, Haji-Momenian S, Nikolaidis P, Miller FH. Adrenal imaging: a comprehensive review. Radiol Clin North Am 2012;50:219-243.

7. Papavramidis TS, Duros V, Michalopoulos A, Papadopoulos VN, Paramythiotis D, Harlaftis N. Intra-abdominal pressure alterations after large pancreatic pseudocyst transcutaneous drainage. BMC Gastroenterol 2009;9:42.

8. Demir A, Tanidir Y, Kaya H, Turkeri LN. A giant adrenal pseudocyst: case report and review of the literature. Int Urol Nephrol 2006;38:167-169.

9. Neri LM, Nance FC. Management of adrenal cysts. Am Surg 1999;65:151163.

10. Aloraifi F, O'Brien G, Broe P. Giant adrenal pseudocyst treated laparoscopically: case report and review of the literature. Open Surg J 2008;2:39-42.

11. Kar M, Pucci E, Brody F. Laparoscopic resection of an adrenal pseudocyst. J Laparoendosc Adv Surg Tech A 2006;16:478-481.

12. Egbert N, Elsayes KM, Azar S, Caoili EM. Computed tomography of adrenocortical carcinoma containing macroscopic fat. Cancer Imaging 2010;10:198-200.

13. Elsayes KM, Mukundan G, Narra VR, Lewis JS Jr, Shirkhoda A, Farooki A Brown JJ. Adrenal masses: $\mathrm{mr}$ imaging features with pathologic correlation. Radiographics 2004;24(Suppl 1):73-86.

14. Blake MA, Kalra MK, Maher MM, Sahani DV, Sweeney AT, Mueller PR, Hahn PF, Boland GW. Pheochromocytoma: an imaging chameleon. Radiographics 2004;24(Suppl 1):87-99.

15. Newhouse $\mathrm{JH}$, Heffess CS, Wagner BJ, Imray TJ, Adair CF, Davidson AJ. Large degenerated adrenal adenomas: radiologic-pathologic correlation. Radiology 1999;210:385-391.

16. Colby GW, Banks KP, Torres E. AJR teaching file: Incidental adrenal mass and hypertension. AJR Am J Roentgenol 2006;187(3 Suppl):470-472. 